Applied Remote Sensing

\title{
Variation and trends of landscape dynamics, land surface phenology and net primary production of the Appalachian Mountains
}

Yeqiao Wang

Jianjun Zhao

Yuyu Zhou

Hongyan Zhang 


\title{
Variation and trends of landscape dynamics, land surface phenology and net primary production of the Appalachian Mountains
}

\author{
Yeqiao Wang, ${ }^{\text {a }}$ Jianjun Zhao, ${ }^{\text {a,b }}$ Yuyu Zhou, ${ }^{\mathrm{c}}$ and Hongyan Zhang ${ }^{\mathrm{b}}$ \\ ${ }^{a}$ University of Rhode Island, Department of Natural Resources Science, Kingston, Rhode \\ Island 02881 \\ yqwang@uri.edu \\ ${ }^{b}$ Northeast Normal University, School of Urban and Environmental Sciences, Changchun, Jilin \\ 130024, China \\ ${ }^{\mathrm{c}}$ Pacific Northwest National Laboratory/University of Maryland, Joint Global Change Research \\ Institute, 5825 University Research Court, Suite 3500, College Park, Maryland 20740
}

\begin{abstract}
The gradients of elevations and latitudes in the Appalachian Mountains provide a unique regional perspective on landscape variations in the eastern United States and southeastern Canada. We reveal patterns and trends of landscape dynamics, land surface phenology, and ecosystem production along the Appalachian Mountains using time series data from Global Inventory Modeling and Mapping Studies and Advanced Very High Resolution Radiometer Global Production Efficiency Model datasets. We analyze the spatial and temporal patterns of the normalized difference vegetation index (NDVI), length of growing season (LOS), and net primary production (NPP) of selected ecoregions along the Appalachian Mountains regions. We compare the results in different spatial contexts, including North America and the Appalachian Trail corridor area. To reveal latitudinal variations, we analyze data and compare the results between the $30^{\circ}$-to- $-40^{\circ} \mathrm{N}$ and the $40^{\circ}$-to- $-50^{\circ} \mathrm{N}$ latitudes. The result reveal significant decreases in annual peak NDVI in the Appalachian Mountains regions. The trend for the Appalachian Mountains regions was a $-0.0018\left(R^{2}=0.55, P<0.0001\right)$ NDVI unit decrease per year during 25 years from 1982 to 2006 . The LOS was prolonged by 0.3 days per year $^{-1}$ during the 25-year percent. The NPP increased by $2.68 \mathrm{~g} \mathrm{Cm}^{-2} \mathrm{yr}^{-2}$ from 1981 to 2000 . () 2012 Society of Photo-Optical Instrumentation Engineers (SPIE). [DOI: 10.1117/1.JRS.6.061708]
\end{abstract}

Keywords: Appalachian Mountains; normalized difference vegetation index; land surface phenology; net primary production; variations and trends.

Paper 12202SS received Jul. 11, 2012; revised manuscript received Nov. 2, 2012; accepted for publication Nov. 29, 2012; published online Dec. 17, 2012.

\section{Introduction}

The Appalachian Mountains, also known as the Appalachians, are a system of mountains in eastern North America. They run from central Alabama to the New England region of the northeast United States and extend into sections of Quebec, New Brunswick, and Newfoundland in Canada. The mountain range forms a natural barrier between the eastern coastal regions and the interior lowlands of northeastern America. The forests of the Appalachians sustain a variety of ecosystems and native biological diversity. The environmental effects and ecosystem functions and services associated with the Appalachians have long been the focus of scientific research in understanding the mountain range as a unique geographic entity and in comparison with different spatial contexts for providing a regional reference and validation.

The Appalachian Trail is an iconic footpath that traverses high-elevation ridges of the Appalachian Mountains. The trail extends over $3500 \mathrm{~km}$ across 14 states in the eastern United States from Springer Mountain in northern Georgia to Mount Katahdin in central Maine. The gradients in elevation, latitude, and moisture sustain a rich biological assemblage of

0091-3286/2012/\$25.00 @ 2012 SPIE 
temperate zone forest species. The north-south alignment of the Appalachian Trail corridor represents a cross-section mega-transect of the eastern U.S. forests and alpine areas and provides a barometer for early detection of undesirable changes in the natural resources, such as development encroachment, acid precipitation, invasions of exotic species, and climate change impacts. ${ }^{1,2}$

Climate change studies reveal the effects of global warming on the growing season of terrestrial vegetation at middle and high latitudes. ${ }^{3,4}$ Over the 20th century, the global average surface temperature increased $0.6 \pm 0.2^{\circ} \mathrm{C}$. Observable warming occurred between 1976 and 2000, and temperatures are projected to increase ${ }^{5,6}$ by $1.4^{\circ} \mathrm{C}$ to $5.8^{\circ} \mathrm{C}$ from 1990 to 2100 . Tracking variations in landscape dynamics provides an understanding of the changing environment, the impacts and threats caused by changes, and the likely trends in the future for natural resources and associated ecosystems. ${ }^{7}$ Time series remote sensing data provide necessary observations in revealing patterns of landscape dynamics either by abrupt change or gradual variations.

The normalized difference vegetation index (NDVI) has been effectively used for monitoring vegetation dynamics. Consistent and long time-series NDVI data are important for analysis of vegetation responses to global change in terrestrial ecosystems. ${ }^{8}$ The Global Inventory Monitoring and Modeling Studies (GIMMS) NDVI dataset derived from Advanced Very High Resolution Radiometer (AVHRR) has been broadly used for studying vegetation activity on regional and global scales.

Phenology studies have long been reported in different domains, such as climate change. ${ }^{9}$ biodiversity, ${ }^{10}$ wildlife ecology,${ }^{11}$ snow dynamics,${ }^{12}$ fire effects, ${ }^{13}$ and crops.${ }^{14}$ Land surface phenology (LSP) is one of the measures of landscape dynamics. It reflects the response of vegetated surfaces to seasonal and annual changes in the climatic and hydrologic cycle. LSP is strongly linked to climatic factors. ${ }^{15}$ It has been broadly studied in the context of ecosystem responses to climate change $\mathrm{e}^{16}$ and for monitoring and understanding global change in vegetation lifecycle events. Because of spatial resolution of remote sensing data, LSP is described as an indicator of mixtures of land covers and is distinct from traditional notion of species-centric phenology, such as seasonal flowering or budburst. ${ }^{17,18}$ Because LSP is based on remote sensing observations at regional and global scales, it serves as a key biological indicator for detecting the response of terrestrial ecosystems to climatic variation.

LSP metrics are primarily based on time series images of vegetation indices from optical sensors such as AVHRR, spot-vegetation (VGT), and moderate resolution imaging spectroradiometer (MODIS). These metrics typically retrieve the time of the onset of greenness as the start of the season (SOS), onset of senescence or time of end of greenness as the end of the season (EOS), timing of the maximum of the growing season by peak vegetation indices, and the length of growing season (LOS) or duration of greenness. An increasing number of studies have reported the shifts in timing and length of the growing season based on phenology, satellite data, and climatological studies. ${ }^{6}$

Net primary production (NPP) plays an important role in the Earth surface system's health ${ }^{19}$ and the terrestrial carbon cycle. ${ }^{20,21} \mathrm{NPP}$ and its response to climate change have been the focus of global change research. ${ }^{22}$ Studies have been conducted based on historical datasets. ${ }^{23-32}$ Recent climatic changes have enhanced plant growth in northern middle and high latitudes. ${ }^{31}$ Various NPP models have been developed to analyze NPP response to climate change. ${ }^{32-42}$ Regional scale carbon cycle processes and climate patterns provide indications of potential responses and feedback to climate change. ${ }^{43}$

Other studies showed that temperatures across the northeastern United States have been increasing steadily since the 1970s. A wide range of indicators in the Northeast have already been observed to be responsive to the changes, which in turn have the potential to impact urban and rural life, agriculture, industry, tourism, and natural ecosystems. ${ }^{44}$ The U.S. Global Change Research Program reported that the annual average temperature in the Northeast has increased by $1.1^{\circ} \mathrm{C}$, with winter temperatures rising twice that much, since 1970 . At the same time, warming has resulted in many other climate-related changes, including more frequent days with temperatures above $32.2^{\circ} \mathrm{C}$, longer growing seasons, increased heavy precipitation, more winter precipitation falling as rain instead of snow, reduced snowpack, earlier breakup of winter ice on lakes and rivers, and earlier spring snowmelt resulting in earlier peak river flows and rising sea surface temperatures and sea levels. ${ }^{45}$ Projections along the Appalachian Trail corridor area 
showed a steady temperature increase ranging from $2^{\circ} \mathrm{C}$ to $6^{\circ} \mathrm{C}$ by the end of the 21 st century. Precipitation, however, did not show any significant trend or decadal variation. ${ }^{46}$

Therefore, the objective of this study is to investigate the patterns and trends of NDVI, LSP, and NPP of the Appalachian Mountains regions and make comparisons of those variables with different scales of spatial contexts using time series GIMMS and Global Production Efficiency Model (GloPEM) datasets. ${ }^{37,47}$

\section{Materials and Methods}

\subsection{Study Areas}

The selected Appalachian Mountains regions consist of four provinces of ecoregions in the United States and Canada covering a latitudinal range between $34^{\circ} 4^{\prime} \mathrm{N}$ and $49^{\circ} 15^{\prime} \mathrm{N}$ and $406,944 \mathrm{~km}^{2}$ in area (Fig. 1). The provinces of ecoregions include the Adirondack-New England Mixed Forest-Coniferous Forest-Alpine Meadow Province, the Eastern Broadleaf Forest Province, and the Central Appalachian Broadleaf Forest-Coniferous Forest-Meadow Province in the United States ${ }^{48}$ and a section of the Eastern Canadian Forests.

The Adirondack-New England Mixed Forest-Coniferous Forest-Alpine Meadow Province has a modified continental climatic regime with long, cold winters and warm summers. Annual precipitation is evenly distributed. The landscape is mountainous and was previously glaciated. Forest vegetation is a transition between boreal on the north and broadleaf deciduous to the south. The Eastern Broadleaf Forest Province has a continental-type climate of cold winters and warm summers. Annual precipitation is greater during the summer. Topography is variable, ranging from plains to low hills of low relief along the Atlantic coast. Interior



Fig. 1 The study area consists of four provinces of ecoregions along the Appalachian Mountains in the eastern United States and southeastern Canada. The selected Appalachian Mountains ecoregion provinces include (A) Eastern Canadian Forests, (B) Adirondack-New England Mixed Forest-Coniferous Forest-Alpine Meadow Province, (C) Eastern Broadleaf Forest Province, and (D) Central Appalachian Broadleaf Forest-Coniferous Forest-Meadow Province. North America and an Appalachian Trail corridor area are selected for the comparative studies. 
areas are high hills to semi-mountainous, parts of which were glaciated. Vegetation is characterized by tall, cold-deciduous broadleaf forests. The Central Appalachian Broadleaf ForestConiferous Forest-Meadow Province is a moderately dissected plateau of irregular plains and open hills. Geologic formations are mostly marine deposits of limestones, shales, and sandstone. The existing land cover type is mainly agricultural and urban. Small areas of natural cover types remain, consisting of forests of oak-hickory, maple-beech-birch, and oak-gum-cypress cover types. The Eastern Canadian Forests are characterized by forested land in eastern Quebec, much of Newfoundland, the highlands of New Brunswick, and Cape Breton Island, Nova Scotia. The climate ranges from high and mid-boreal and perhumid mid-boreal to Oceanic, Atlantic, and maritime mid-boreal. Summers are generally cool, with average temperatures ranging from $8.5^{\circ} \mathrm{C}$ in the north to $14.5^{\circ} \mathrm{C}$ in the south. Winter temperatures vary according to the proximity to the ocean and continental landmass.

In order to reveal the differences and similarities of NDVI, SOS, and NPP in the Appalachian Mountains regions, we compared the variables in different spatial scales with North America and the Appalachian Trail corridor area (Fig. 1), and in different latitudinal ranges from $30^{\circ} \mathrm{N}$ to $40^{\circ} \mathrm{N}$ and $40^{\circ} \mathrm{N}$ to $50^{\circ} \mathrm{N}$ in North America.

\subsection{Datasets}

GIMMS $^{49}$ data derived from AVHRR have been used extensively for global-scale vegetation monitoring and detection of trends in vegetation conditions. ${ }^{50}$ GIMMS data provide global time series NDVI measurements at a spatial resolution of $8 \times 8 \mathrm{~km}^{2}$. The data are composited over a period of approximately 15 days with the maximum value compositing (MVC) technique $^{51}$ to reduce cloud cover and to maintain temporal frequency. The data have been corrected for calibration, view geometry, volcanic aerosols, and other effects not related to vegetation change. ${ }^{49,52-55}$ GIMMS data have been used broadly in LSP studies. ${ }^{15,56-63}$ The GIMMS data were fitted yearly with a Gaussian function to generate smoothed data for each of the 25 years from 1982 to 2006 . We used monthly composites of GIMMS data to calculate the LSP metrics. The NPP dataset estimated by AVHRR GloPEM was designed to run with both biological and environmental variables derived. ${ }^{37,47}$ The GloPEM dataset is available from 1981 to 2000 in 10-day periods or a summed annual level. The dataset is derived from AVHRR images at an $8-\mathrm{km}$ resolution from the AVHRR Pathfinder Project.

\subsection{Land Surface Phenology Metrics}

The methods to obtain LSP metrics include thresholds, derivatives, smoothing functions, and fitted models. ${ }^{64}$ The TIMESAT software program ${ }^{65,66}$ is among those widely used ${ }^{12,13,67-70}$ In order to reduce dropouts or gaps from long time-series data, TIMESAT uses SavitzkyGolay filtering, asymmetrical Gaussian, or double logistic functions for fitting NDVI data. ${ }^{71}$ The local Savitzky-Golay function can capture subtle and rapid changes in the time series, but it is also sensitive to noise. The asymmetrical Gaussian and double logistic functions are less sensitive to the noise and can derive a better description of the beginnings and endings of the seasons. ${ }^{65,72}$ In this study, we adopted the asymmetrical Gaussian approach:

$$
g\left(t ; x_{1}, x_{2}, x_{3}, x_{4}, x_{5}\right)=\left\{\begin{array}{ll}
\exp \left[-\left(\frac{t-x_{1}}{x_{2}}\right)^{x_{1}}\right] & \text { if } t>x_{1} \\
\exp \left[-\left(\frac{x_{1}-t}{x_{4}}\right)^{x_{5}}\right] & \text { if } t<x_{1}
\end{array},\right.
$$

where $x_{1}$ determines the position of the maximum or minimum with respect to the independent time variable $t, x_{2}$ and $x_{3}$ determine the width and flatness (kurtosis) of the right half function, and $x_{4}$ and $x_{5}$ determine the width and flatness of the left half function. ${ }^{2,71}$

In order to make comparisons of LSP in different scales, we employed the GIMMS and the phenology data from the USDA Forest Service that possess 231-m spatial resolution and cover the time period from 2003 to 2006 . We then determined the parameter. The SOS is defined as the 
time for which the left edge has increased to $20 \%$ (seasonal amplitude from minimum NDVI to maximum NDVI) measured from the left minimum NDVI. The EOS is defined as the time for which the right edge has decreased to $20 \%$ (seasonal amplitude from minimum NDVI to maximum NDVI) measured from the right minimum NDVI. The LOS is the time period measured in days from the SOS to the EOS. We built the smooth time series of NDVI from TIMESAT. We derived the LSP metrics based on and adopted the adaptation strength of 2.0, no spike filtering, and amplitude. We calculated the SOS and EOS for each year and obtained LOS as the difference between SOS and EOS in each grid cell. In this paper, we analyzed the spatial and temporal variation of LOS in the study areas. We used the nonparametric Mann-Kendall test for testing the presence of the monotonic increasing or decreasing trends and the Sen's method for estimating the slope of linear trends of annual peak values of NDVI, LOS, and NPP.

\section{Results}

\subsection{Spatial Pattern Of NDVI, LSP, and NPP}

Figure 2 illustrates spatial patterns of the mean value of peak NDVI, LSP, NPP, Temperature, Precipitation, and Land Cover. The peak NDVI, LSP, and NPP represent the maximum value of the year and were obtained using the MVC method. The mean peak NDVI, LSP, and NPP were obtained similarly. Land cover types were considered in obtaining the spatial variation of NDVI, as shown in Fig. 2(a) and 2(f). For example, forests are mainly distributed in humid climatic zones of the Appalachian Mountains ${ }^{73}$ and therefore possess high NDVI values. At pixel scale, the data illustrate spatial dynamics of LOS of the Appalachian Mountains between 1982 and 2006. The spatial variation indicates that the average LOS varied from 144 to 262 days, and extended LOS was observed in low-latitude areas, as shown in Fig. 2(b). The patterns indicate that LOS increased from northeast to southwest in these areas. Spatial pattern reveals that LOS was more responsive to the variation of temperature [Fig. 2(d)] than to precipitation [Fig. 2(e)]. Annual mean NPP ranged from 450 to $1,541 \mathrm{~g} \mathrm{Cm}^{-2} \mathrm{yr}^{-1}$ [Fig. 2(c)] in the Appalachian Mountains over the 20 years from 1991 to 2000. NPP values reflected the latitudinal effects from southwest to northeast at $34^{\circ} \mathrm{N}$ to $40^{\circ} \mathrm{N}, 40^{\circ} \mathrm{N}$ to $45^{\circ} \mathrm{N}$, and $45^{\circ} \mathrm{N}$ to $50^{\circ} \mathrm{N}$. Areas with low NPP were found in the high-latitude regions, consistent with the changes in temperature [Fig. 2(d)]. The pattern of temperature variation showed a decreasing trend from southwest to northeast. The mean temperature showed high values from $34^{\circ} \mathrm{N}$ to $40^{\circ} \mathrm{N}$, medium values from $40^{\circ} \mathrm{N}$ to $45^{\circ} \mathrm{N}$, and low values from $45^{\circ} \mathrm{N}$ to $50^{\circ} \mathrm{N}$. The precipitation was highest with 2,181 mm/year in the low-latitude regions, as shown in Fig. 2(e). In the southwestern region, the NPP, temperature, and precipitation measures were higher than those in other regions. A combination of higher temperature and precipitation contributes to high NPP in the southwestern region of the Appalachian Mountains.

\subsection{Trends Of NDVI, LSP, and NPP}

The trend of NDVI in the Appalachian Mountains regions varied from -0.012 to 0.0056 units. The declining trends of peak NDVI occurred in the Appalachian Mountains, particularly in the central regions [Fig. 3(a)]. Only the section area within the Eastern Canadian Forests showed increasing trends of peak NDVI.

Spatial variations in LOS trends indicate that LOS varied between -2.34 days (decreasing) to 2.97 days (increasing) per year from 1982 to 2006 over the Appalachian Mountains regions [Fig. 3(b)]. The decreasing trends $\left(<-1\right.$ days $\left.\mathrm{yr}^{-1}\right)$ were mainly found in the Central Appalachian Broadleaf Forest-Coniferous Forest-Meadow Province and the Eastern Canadian Forests. Positive LOS trends mainly occurred in the Adirondack-New England Mixed ForestConiferous Forest-Alpine Meadow Province, as shown in Fig. 3(b).

We calculated the trends in NPP at the pixel level $(8 \mathrm{~km})$ from 1981 to 2000 using linear least squares. These calculations are shown in Fig. 3(c). Positive and negative NPP trends were found across the Appalachian Mountains regions. Observable increases occurred in the Central Appalachian Broadleaf Forest-Coniferous Forest-Meadow Province and the Northeastern 
Wang et al.: Variation and trends of landscape dynamics, land surface phenology...
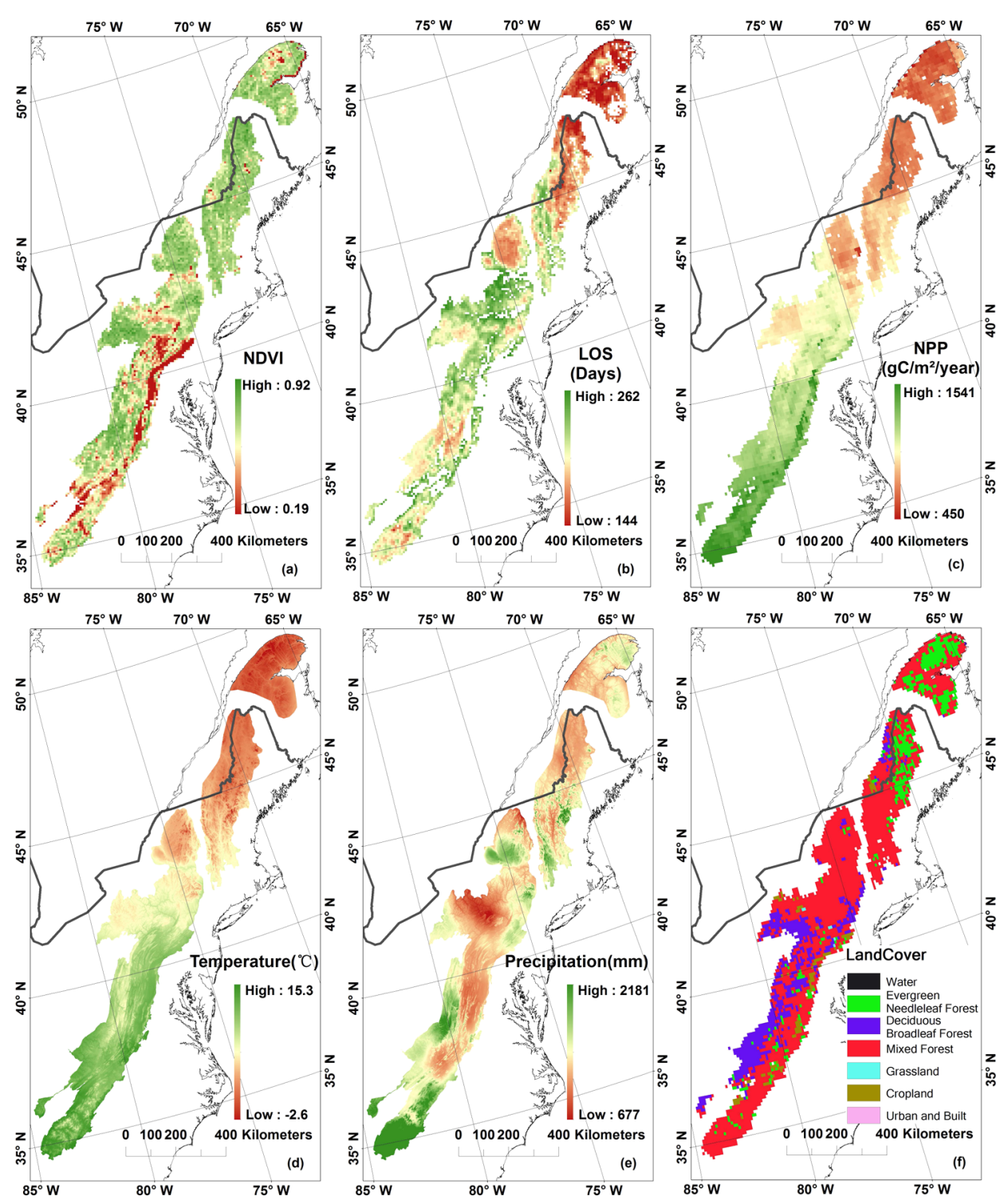

Fig. 2 The spatial patterns of mean peak NDVI, LSP, NPP, Temperature, Precipitation, and Land Cover of the studied Appalachian Mountains regions.

Mixed Forest Province. A decrease in NPP occurred in the northeast, and an increased trend was observed in the southwest of the Appalachian Mountains.

\subsection{Comparison of Appalachian Mountains with Different Spatial Contexts}

The NDVI data were calculated for vegetated area only. For Figs. 4-6, the straight lines were generated using the method of linear least squares. Significant decrease in annual peak NDVI was observed in the Appalachian Mountains, as well as the Appalachian Trail corridor area (Fig. 4). The average slope in the Appalachian Mountains was a $-0.0018\left(R^{2}=0.55\right.$, $P<0.0001)$ NDVI unit decrease per year during the 25 years from 1982 to 2006 . For the Appalachian Trail corridor area, the average slope was a $-0.0022\left(R^{2}=0.62, P<0.0001\right)$ NDVI unit decrease per year over the 25 years. However, there was no observable trend in North America or in the selected latitudinal ranges from $30^{\circ} \mathrm{N}$ to $40^{\circ} \mathrm{N}$ and from $40^{\circ} \mathrm{N}$ to $50^{\circ} \mathrm{N}$ (Fig. 4 and Table 1).

The prolonged LOS was 0.3 day $\mathrm{yr}^{-1}$ over the entire Appalachian Mountains, 0.39 day $\mathrm{yr}^{-1}$ in latitudinal zone from $40^{\circ} \mathrm{N}$ to $50^{\circ} \mathrm{N}, 0.02$ day $\mathrm{yr}^{-1}$ in North America, and $0.28 \mathrm{day} \mathrm{yr}^{-1}$ in the 
Wang et al.: Variation and trends of landscape dynamics, land surface phenology...
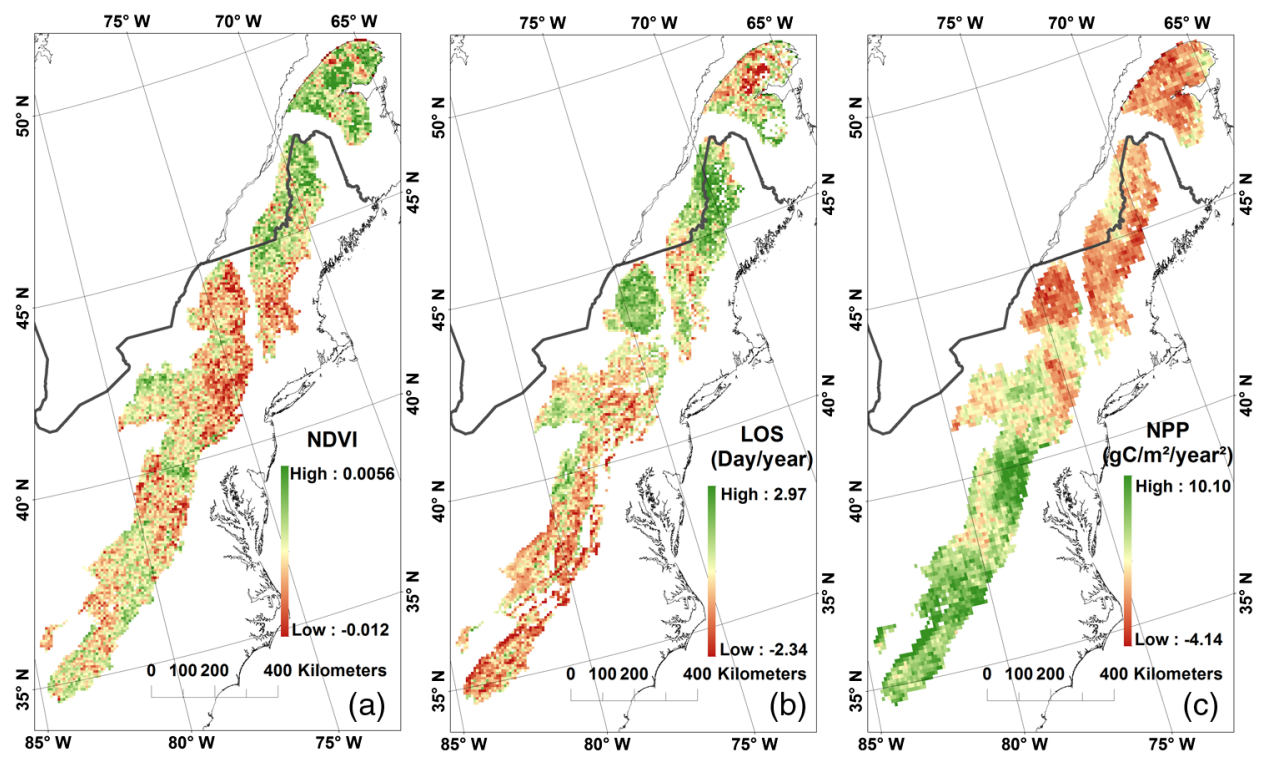

Fig. 3 Trends in peak NDVI, LOS, and NPP within the selected Appalachian Mountains regions from 1982 to 2006.

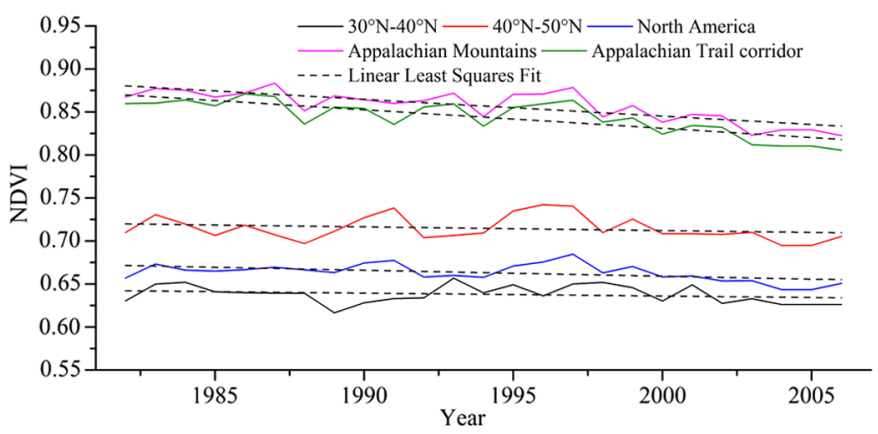

Fig. 4 The interannual variability of NDVI for the Appalachian Mountains, North America, the $30^{\circ}$ $\mathrm{N}-40^{\circ} \mathrm{N}$ range in North America, the $40^{\circ}-50^{\circ} \mathrm{N}$ range in North America, and the Appalachian Trail corridor area between 1982 and 2006.

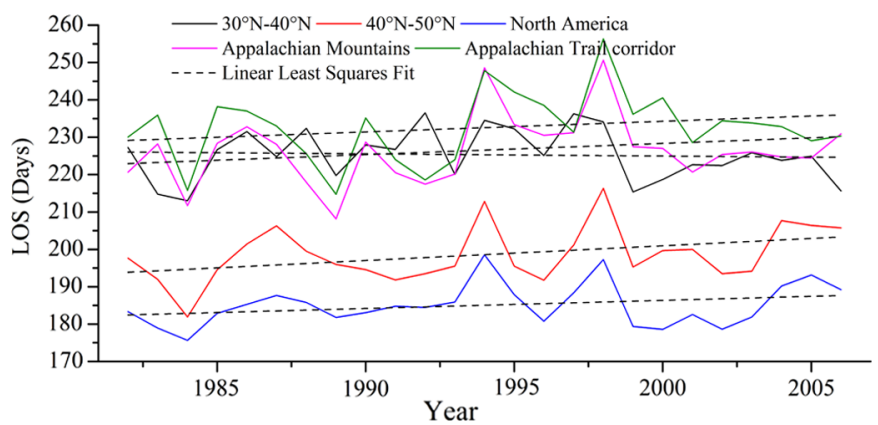

Fig. 5 The variation of LOS for the Appalachian Mountains, North America, the $30^{\circ} \mathrm{N}-40^{\circ} \mathrm{N}$ range in North America, the $40^{\circ} \mathrm{N}-50^{\circ} \mathrm{N}$ range in North America, and the Appalachian Trail corridor area. 
Wang et al.: Variation and trends of landscape dynamics, land surface phenology...

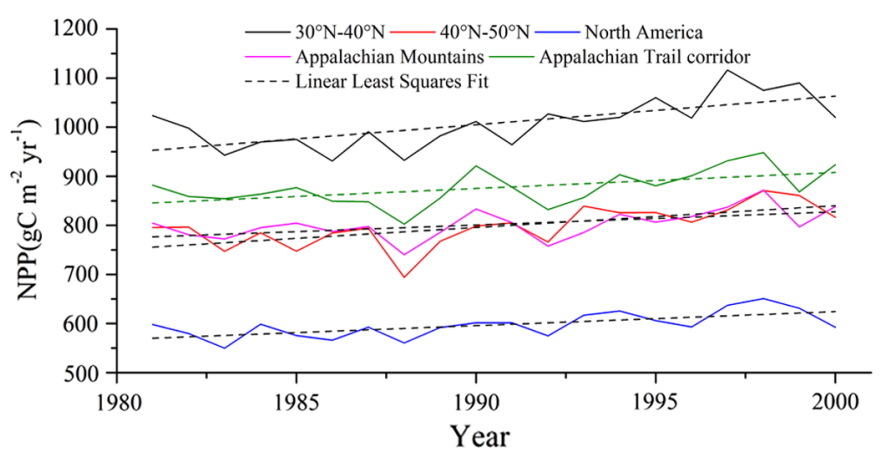

Fig. 6 The variation in NPP for the Appalachian Mountains, North America, the $30^{\circ} \mathrm{N}-40^{\circ} \mathrm{N}$ range in North America, the $40^{\circ} \mathrm{N}-50^{\circ} \mathrm{N}$ range in North America, and the Appalachian Trail corridor area.

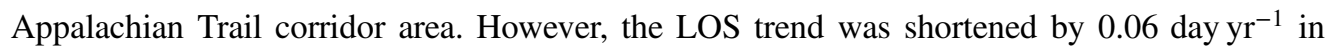
latitudes from $30^{\circ} \mathrm{N}$ to $40^{\circ} \mathrm{N}$. Although there was no indication of a significant trend in LOS in any region during the study time periods, abnormal values in some years (e.g., 1998 and 1999) were observable against the calculated mean values and are shown in Fig. 5.

We calculated the annual mean NPP values for the Appalachian Mountains, North America, and the Appalachian Trail corridor area (Fig. 6 and Table 1). The average NPP values were $1,008,797,597,802$, and $876 \mathrm{~g} \mathrm{Cm}^{-2} \mathrm{yr}^{-1}$, in the $30^{\circ} \mathrm{N}-40^{\circ} \mathrm{N}$ range, the $40-50^{\circ} \mathrm{N}$ range, North America, the Appalachian Mountains, and the Appalachian Trail corridor area,

Table 1. The parameters of NDVI, LOS, and NPP

\begin{tabular}{|c|c|c|c|c|c|c|}
\hline & Parameter & $\begin{array}{c}30^{\circ} \mathrm{N}-40^{\circ} \\
\mathrm{N}\end{array}$ & $\begin{array}{c}40^{\circ} \mathrm{N}-50^{\circ} \\
\mathrm{N}\end{array}$ & $\begin{array}{c}\text { North } \\
\text { America }\end{array}$ & $\begin{array}{l}\text { Appalachian } \\
\text { Mountains }\end{array}$ & $\begin{array}{c}\text { Appalachian } \\
\text { Trail } \\
\text { Corridor }\end{array}$ \\
\hline \multirow{6}{*}{$\begin{array}{l}\text { NDVI } \\
1982- \\
2006\end{array}$} & Max & 0.6567 & 0.7404 & 0.6422 & 0.8865 & 0.8715 \\
\hline & Min & 0.6167 & 0.6931 & 0.6032 & 0.8267 & 0.8047 \\
\hline & Mean & 0.6380 & 0.7135 & 0.6208 & 0.8603 & 0.8430 \\
\hline & Slope & -0.0004 & -0.0004 & -0.0004 & -0.0018 & -0.0022 \\
\hline & $R^{2}$ & 0.0194 & 0.0132 & 0.0432 & 0.5505 & 0.6202 \\
\hline & $P$ & 0.2369 & 0.2622 & 0.1624 & 0.0000 & 0.0000 \\
\hline \multirow{6}{*}{$\begin{array}{l}\text { LOS } \\
1982- \\
2006\end{array}$} & Max & 237 & 216 & 199 & 251 & 256 \\
\hline & Min & 213 & 182 & 176 & 208 & 215 \\
\hline & Mean & 225 & 199 & 185 & 227 & 233 \\
\hline & Slope & -0.0588 & 0.3937 & 0.2167 & 0.3000 & 0.2841 \\
\hline & $R^{2}$ & -0.0394 & 0.1126 & 0.0396 & 0.0149 & 0.0085 \\
\hline & $P$ & 0.7651 & 0.0561 & 0.1718 & 0.2550 & 0.2836 \\
\hline \multirow{6}{*}{$\begin{array}{l}\text { NPP } \\
1981- \\
2000\end{array}$} & Max & 1117 & 871 & 651 & 872 & 948 \\
\hline & Min & 931 & 694 & 550 & 740 & 802 \\
\hline & Mean & 1009 & 797 & 597 & 802 & 877 \\
\hline & Slope & 5.7980 & 4.4441 & 2.8544 & 2.6820 & 3.2669 \\
\hline & $R^{2}$ & 0.4347 & 0.3731 & 0.3879 & 0.2399 & 0.2485 \\
\hline & $P$ & 0.0009 & 0.0025 & 0.0020 & 0.0165 & 0.0147 \\
\hline
\end{tabular}


respectively. The increasing trend in NPP was observed for all the regions during the 20-year period (Fig. 6). The NPP increased $2.68 \mathrm{~g} \mathrm{Cm}^{-2} \mathrm{yr}^{-2}\left(R^{2}=0.24, P=0.016\right)$ from 1982 to 2006 in Appalachian Mountains. The trends in NPP showed an increase of $5.80 \mathrm{~g} \mathrm{Cm}^{-2} \mathrm{yr}^{-2}$ $\left(R^{2}=0.43, \quad P<0.0009\right) \quad$ in $\quad$ the $30^{\circ} \mathrm{N}-40^{\circ} \mathrm{N}$ range, $4.44 \mathrm{~g} \mathrm{Cm}^{-2} \mathrm{yr}^{-2} \quad\left(R^{2}=0.37\right.$, $P=0.0025)$ in the $40^{\circ} \mathrm{N}-50^{\circ} \mathrm{N}$ range, $2.85 \mathrm{~g} \mathrm{Cm}^{-2} \mathrm{yr}^{-2}\left(R^{2}=0.39, P=0.002\right)$ in North America, and $2.17 \mathrm{~g} \mathrm{Cm}^{-2} \mathrm{yr}^{-2}\left(R^{2}=0.25, P=0.015\right)$ in the Appalachian Trail corridor.

\section{Conclusions and Discussion}

This study revealed the spatial and temporal variations and trends in landscape dynamics, LSP, and NPP in the study area. The comparisons examined the Appalachian Mountains as a unique geographic entity and their topographic and elevation effects in the spatial context. Our conclusions are as follows.

The peak NDVI values decreased significantly in the Appalachian Mountains and the Appalachian Trail corridor area (Fig. 4). Both trends possessed higher negative slopes than those in the $30^{\circ} \mathrm{N}-40^{\circ} \mathrm{N}$ and $40^{\circ} \mathrm{N}-50^{\circ} \mathrm{N}$ latitudinal zones and North America. The mean peak NDVI values were 0.86 in the Appalachian Mountains and 0.84 in the Appalachian Trail corridor, higher than those of North America. Other studies have suggested that the average annual peak NDVI presented a declining trend over many protected areas in North America. ${ }^{50}$ Given that neither temperature nor precipitation showed a correlation with NDVI, this may imply that the observed decrease in NDVI was mainly driven by the combination of urban expansion and outbreaks of hemlock wooly adelgids (Adelges tsugae) ${ }^{74-76}$ and other insect pests. Consistent with the patterns observed in the AVHRR GIMMS data along the Appalachian Trail corridor, analyses using other types of remote sensing data have shown a decrease in forest cover in the eastern U.S., mainly due to the growth of urban areas since the 1970s. ${ }^{7,77-79}$

There are different results from different methods for calculation of LSP parameters. ${ }^{64}$ For example, the results from four methods were very much different. The SOS calculated by the moving average method was the lowest, and the EOS value was the highest, but the derivative method delivered the highest SOS value and the lowest EOS value.

A reported LSP study suggested that the EOS in North America was delayed by 8.1 days per decade from 1982 to 1999 and by 1.3 days per decade from 2000 to $2008{ }^{80}$ Another study reported that SOS advanced by approximately 8 days, EOS was delayed by 4 days, and LOS increased by 12 days in North America from 1982 to $1999 .{ }^{81}$ The results of this study suggested that LOS in the Appalachian Mountains advanced 7.5 days from 1982 to 2006. The longest annual mean LOS value (233 days) was observed in the Appalachian Trail corridor area, and the second longest LOS value (227 days) was observed in the Appalachian Mountains regions. The mean LOS in the latitudinal range between $40^{\circ} \mathrm{N}$ and $50^{\circ} \mathrm{N}$ increased by 0.39 days $\mathrm{yr}^{-1}\left(R^{2}=0.11, P=0.056\right)$ from 1982 to 2006 ; that increase was higher than those in other regions. The overall trend along the Appalachian Mountains, despite local variations, agreed with broader patterns obtained for the Northern Hemisphere and North America. The local variations were caused by topographic and elevation effects, as well as associated land cover types and ecosystems.

To further understand the effect of elevation, we divided the LOS into 20 categories from $-5 \mathrm{~m}$ to $2,025 \mathrm{~m}$. We found that the LOS was shortened by 1.2 days $\left(R^{2}=0.86, P<0.001\right)$ for every $100-\mathrm{m}$ increase in elevation. The prolonged LOS was mainly attributed to delayed EOS. This study concluded that the variations and trends of LSP metrics in the Appalachian Mountains were comparable to those obtained for the Appalachian Trail corridor area ${ }^{82}$ The LOS anomalies in 1987, 1994, and 1998 followed the pattern of warm and cold episodes based on a threshold of $+/-0.5^{\circ} \mathrm{C}$ for the Oceanic Niño Index (ONI). The reversed LOS patterns correspond to El Niño in 1997 to 1998 and La Niña in 1999 to 2000 events. ${ }^{83}$ This indicates that LOS is sensitive to climate variations.

NPP modeling studies have documented that terrestrial photosynthetic activity has increased over the past two to three decades in the middle and high latitudes in the Northern Hemisphere. ${ }^{28-30,32,84}$ The mean annual NPP in North America (north of $22^{\circ} \mathrm{N}$ ) was reported as $6.2 \mathrm{PgC} \mathrm{yr}^{-1}$, increasing by $0.028 \mathrm{PgC} \mathrm{yr}^{-2}$ (significant at the $99 \%$ level) from 1982 to 
$1998{ }^{28}$ The results from this study illustrated significant increasing trends of NPP from 1981 to 2000 in all the study regions. The NPP in the Appalachian Mountains increased by $2.68 \mathrm{~g} \mathrm{Cm}^{-2} \mathrm{yr}^{-2}\left(R^{2}=0.24, P=0.017\right)$, a smaller rate than that for North America (2.85 $\left.\mathrm{g} \mathrm{Cm}^{-2} \mathrm{yr}^{-2}, \quad R^{2}=0.39, \quad P=0.002\right)$. The largest annual mean NPP value $\left(1009 \mathrm{~g} \mathrm{Cm}^{-2} \mathrm{yr}^{-1}\right)$ and the largest trend increase $\left(5.8 \mathrm{~g} \mathrm{Cm}^{-2} \mathrm{yr}^{-2}, R^{2}=0.43, P=0.0009\right)$ were observed in the latitudinal range between $30^{\circ} \mathrm{N}$ and $40^{\circ} \mathrm{N}$. The mean NPP in the Appalachian Trail corridor area increased by $3.23 \mathrm{~g} \mathrm{Cm}^{-2} \mathrm{yr}^{-2}\left(R^{2}=0.25, P=0.015\right)$, which was larger than that for North America and smaller than that for the Appalachian Mountains regions.

While prolonged LOS and increasing trends of annual NPP were observed in the Appalachian Mountains and the Appalachian Trail corridor, peak NDVI showed a decreasing trend. There are many factors that could affect the change of NDVI, LOS, and NPP in different spatial contexts of the study areas. The similar pattern of variations and trends between the Appalachian Trail corridor area and the Appalachian Mountains regions suggested that the Appalachian Trail corridor area can serve as a mega-transect to reflect such variations and trends of the Appalachian Mountains regions.

\section{Acknowledgments}

This study was funded by NASA Science Mission Directorate (ROSES-2008) Decision Support through Earth Science Research Results under the project "A Decision Support System for Monitoring, Reporting and Forecasting Ecological Conditions of the Appalachian National Scenic Trail" (Grant NNX09AV82G). In particular, the authors thank the contributions of those who are on the project team to develop the decision support system: Peter August, Roland Duhaime, Christopher Damon, John Clark, Fu Luo, Charles LaBash, and Peter Paton from the University of Rhode Island; Forrest Melton, Hirofumi Hashimoto, Samuel Hiatt, and Ramakrishna Nemani from the NASA Ames Research Center; Fred Dieffenbach, Matt Robison, Casey Reese, and Brian Mitchell from the National Park Service; Ken Stolte from the USDA Forest Service; Glenn Holcomb and Marcia McNiff from the USGS; and Paul Mitchell from the Appalachian Trail Conservancy. Dr. William Hargrove of the Eastern Forest Environmental Threat Assessment Center, USDA Forest Service, provided the 231-m spatial resolution phenology data. The authors wish to express their sincere appreciation for the critiques and suggestions from anonymous reviewers that helped improve the quality of the manuscript.

\section{References}

1. C.Dufour and E. Crisfield, eds., The Appalachian Trail MEGA-Transect, Appalachian Trail Conservancy, Harpers Ferry, WV (2008).

2. J. Zhao et al., "The variation of land surface phenology from 1982 to 2006 along the Appalachian Trail," IEEE Trans. Geosci. Rem. Sens. 51(4) (2013), http://dx.doi.org/10 .1109/TGRS.2012.2217149.

3. R. B. Myneni et al., "Increased plant growth in the northern high latitudes from 1981 to 1991," Nature 386(6626), 698-702 (1997), http://dx.doi.org/10.1038/386698a0.

4. X. Zhang et al., "The footprint of urban climates on vegetation phenology," Geophys. Res. Lett. 31(12), L12209 (2004), http://dx.doi.org/10.1029/2004GL020137.

5. J. T.Houghton et al., eds., Climate Change 2001: The Scientific Basis: Contribution of Working Group I to the Third Assessment Report of the Intergovernmental Panel on Climate Change (2001).

6. H. W. Linderholm, "Growing season changes in the last century," Agric. Forest Meteorol. 137(1-2) 1-14 (2006), http://dx.doi.org/10.1016/j.agrformet.2006.03.006.

7. Y. Wang et al., "Remote sensing of land-cover change and landscape context of the National Parks: a case study of the Northeast Temperate Network," Rem. Sens. Environ. 113(7), 1453-1461 (2009), http://dx.doi.org/10.1016/j.rse.2008.09.017.

8. M. Brown et al., "Neural networks as a tool for constructing continuous NDVI time series from AVHRR and MODIS," Int. J. Rem. Sens. 29(24), 7141-7158 (2008), http://dx.doi.org/ $10.1080 / 01431160802238435$. 
Wang et al.: Variation and trends of landscape dynamics, land surface phenology...

9. F.-W. Badeck et al., "Responses of spring phenology to climate change," New Phytol. 162(2), 295-309 (2004), http://dx.doi.org/10.1111/nph.2004.162.issue-2.

10. A. H. Hurlbert and J. P. Haskell, "The effect of energy and seasonality on avian species richness and community composition," Am. Natural. 161(1), 83-97 (2003), http://dx.doi .org/10.1086/an.2003.161.issue-1.

11. M. Hebblewhite, E. Merrill, and G. McDermid, "A multi-scale test of the forage maturation hypothesis in a partially migratory ungulate population," Ecol. Monogr. 78(2), 141-166 (2008), http://dx.doi.org/10.1890/06-1708.1.

12. A. M. Jönsson et al., "Annual changes in MODIS vegetation indices of Swedish coniferous forests in relation to snow dynamics and tree phenology," Rem. Sens. Environ. 114(11), 2719-2730 (2010), http://dx.doi.org/10.1016/j.rse.2010.06.005.

13. W. J. D. Van Leeuwen, "Monitoring the effects of forest restoration treatments on post-fire vegetation recovery with MODIS multitemporal data," Sensors 8(3), 2017-2042 (2008), http://dx.doi.org/10.3390/s8032017.

14. T. Sakamoto et al., "A crop phenology detection method using time-series MODIS data," Rem. Sens. Environ. 96(3-4) 366-374 (2005), http://dx.doi.org/10.1016/j.rse.2005 .03.008.

15. B. W. Heumann et al., "AVHRR derived phenological change in the Sahel and Soudan, Africa, 1982-2005," Rem. Sens. Environ. 108(4), 385-392 (2007), http://dx.doi.org/10 $.1016 /$ j.rse.2006.11.025.

16. E. E. Cleland et al., "Shifting plant phenology in response to global change," Trends Ecol. Evol. 22(7), 357-365 (2007), http://dx.doi.org/10.1016/j.tree.2007.04.003.

17. K. M. de Beurs and G. M. Henebry, "Land surface phenology, climatic variation, and institutional change: Analyzing agricultural land cover change in Kazakhstan," Remote Sensing of Environment 89(4), 497-509 (2004), http://dx.doi.org/10.1016/j.rse.2003.11 .006 .

18. M. Friedl et al., "Land surface phenology," A Community White Paper requested by NASA (2006).

19. S. W. Running, P. E. Thornton, R. R. Nemani, and J. M. Glassy, "Global terrestrial gross and net primary productivity from the Earth Observing System," in Methods in Ecosystem Science, O.Sala, R. Jackson, and H. Mooney, eds., Springer-Verlag, New York, pp. 4457 (2000).

20. C. D. Keeling, J. F. S. Chin, and T. P. Whorf, "Increased activity of northern vegetation inferred from atmospheric CO2 measurements," Nature 382(6587), 146-149 (1996), http://dx.doi.org/10.1038/382146a0.

21. C. B. Field et al., "Primary production of the biosphere: integrating terrestrial and oceanic components," Science 281(5374), 237-240 (1998), http://dx.doi.org/10.1126/science.281 .5374 .237 .

22. W. Cramer et al., "Comparing global models of terrestrial net primary productivity (NPP): overview and key results," Global Change Biology 5(S1), 1-15 (1999), http://dx.doi.org/10 .1046/j.1365-2486.1999.00009.x.

23. J. M. Melillo et al., "Global climate change and terrestrial net primary production," Nature 363(6426), 234-240 (1993), http://dx.doi.org/10.1038/363234a0.

24. C. M. Malmström et al., "Interannual variation in global-scale net primary production: Testing model estimates," Global Biogeochem. Cycles 11(3), 367-392.http://dx.doi.org/ 10.1029/97GB01419

25. C. Peng and M. J. Apps, "Modelling the response of net primary productivity (NPP) of boreal forest ecosystems to changes in climate and fire disturbance regimes," Ecol. Modell. 122(3), 175-193 (1999), http://dx.doi.org/10.1016/S0304-3800 (99)00137-4.

26. D. Schimel et al., "Contribution of Increasing $\mathrm{CO}_{2}$ and Climate to Carbon Storage by Ecosystems in the United States," Science 287(5460), 2004-2006 (2000), http://dx.doi .org/10.1126/science.287.5460.2004.

27. W. Lucht et al., "Climatic control of the high-latitude vegetation greening trend and Pinatubo effect," Science 296(5573), 1687-1689 (2002), http://dx.doi.org/10.1126/ science. 1071828. 
Wang et al.: Variation and trends of landscape dynamics, land surface phenology...

28. J. A. Hicke et al., "Satellite-derived increases in net primary productivity across North America, 1982-1998," Geophys. Res. Lett. 29, 4 (2002), http://dx.doi.org/10.1029/ 2001GL013578.

29. M. Cao et al., "Response of terrestrial carbon uptake to climate interannual variability in China," Global Change Biol. 9(4), 536-546 (2003), http://dx.doi.org/10.1046/j.1365-2486 .2003.00617.x.

30. J. Fang et al., "Increasing net primary production in China from 1982 to 1999," Front. Ecol. Environ. 1(6), 293-297 (2003), http://dx.doi.org/10.1890/1540-9295(2003)001[0294: INPPIC]2.0.CO;2.

31. R. R. Nemani et al., "Climate-driven increases in global terrestrial net primary production from 1982 to 1999," Science 300(5625), 1560-1563 (2003), http://dx.doi.org/10.1126/ science. 1082750.

32. S. Piao, J. Fang, and J. He, "Variations in Vegetation Net Primary Production in the QinghaiXizang Plateau, China, from 1982 to 1999," Climat. Change 74(1), 253-267 (2006), http:// dx.doi.org/10.1007/s10584-005-6339-8.

33. S. J. Goetz and S. D. Prince, "Remote sensing of net primary production in boreal forest stands," Agric. For. Meteorol. 78(3-4), 149-179 (1996), http://dx.doi.org/10.1016/01681923(95)02268-6.

34. S. L. Piao, J. Y. Fang, and Q.-H. Guo, "Application of CASE model to the estimation of Chinese terrestrial net primary productivity," Acta Phytoecol. Sin. 25(5), 603-608 (2001).

35. C. S. Potter et al., "Terrestrial ecosystem production: a process model based on global satellite and surface data," Global Biogeochem. Cycles 7(4), 811-841 (1993), http://dx.doi.org/ $10.1029 / 93 \mathrm{~GB} 02725$.

36. A. K. Prasad et al., "Crop yield estimation model for Iowa using remote sensing and surface parameters," Int. J. Appl. Earth Observ. Geoinform. 8(1), 26-33 (2006), http://dx.doi.org/10 .1016/j.jag.2005.06.002.

37. S. D. Prince and S. N. Goward, "Global primary production: a remote sensing approach," J. Biogeogr. 22(4/5), 815-835 (1995), http://dx.doi.org/10.2307/2845983.

38. J. Seaquist, L. Olsson, and J. Ardö, "A remote sensing-based primary production model for grassland biomes," Ecol. Modell. 169(1), 131-155 (2003), http://dx.doi.org/10.1016/ S0304-3800(03)00267-9.

39. S. Sitch et al., "Evaluation of ecosystem dynamics, plant geography and terrestrial carbon cycling in the LPJ dynamic global vegetation model," Global Change Biol. 9(2), 161-185 (2003), http://dx.doi.org/10.1046/j.1365-2486.2003.00569.x.

40. C. Tottrup and M. S. Rasmussen, "Mapping long-term changes in savannah crop productivity in Senegal through trend analysis of time series of remote sensing data," Agric. Ecosyst. Environ. 103(3), 545-560 (2004), http://dx.doi.org/10.1016/j.agee.2003.11.009.

41. B. Wang et al., "Comparison of net primary productivity in karst and non-karst areas: a case study in Guizhou Province, China," Environ. Earth Sci. 59(6), 1337-1347 (2010), http://dx .doi.org/10.1007/s12665-009-0121-6.

42. Y. Zhou et al., "Observation and simulation of net primary productivity in Qilian Mountain, western China," J. Environ. Manage. 85(3), 574-584 (2007), http://dx.doi.org/10.1016/j .jenvman.2006.04.024.

43. D. P. Turner, S. V. Ollinger, and J. S. Kimball, "Integrating remote sensing and ecosystem process models for landscape- to regional-scale analysis of the carbon cycle," BioScience 54(6), 573-584 (2004), http://dx.doi.org/10.1641/0006-3568(2004)054[0573:IRSAEP]2.0 .CO;2.

44. K. Hayhoe et al., "Past and future changes in climate and hydrological indicators in the US Northeast," Climate Dynam. 28(4), 381-407 (2007), http://dx.doi.org/10.1007/s00382-0060187-8.

45. T. R.Karl et al., Eds., Global Climate Change Impacts in the United States, 1st ed., Cambridge University Press, New York (2009).

46. H. Hashimoto et al., "Monitoring and forecasting climate impacts on ecosystem dynamics in protected areas using the terrestrial observation and prediction system," in Remote Sensing of Protected Lands, Y.Wang, Ed., pp. 523-540, CRC Press, Boca Raton, Florida (2011). 
Wang et al.: Variation and trends of landscape dynamics, land surface phenology...

47. S. Prince and J. Small, "Global Production Efficiency Model, 1997_npp_latlon," Department of Geography, University of Maryland, College Park, MD (2003).

48. W. H. McNab et al., "Description of ecological subregions: sections of the conterminous United States [CD-ROM]," US Department of Agriculture, Forest Service, Washington, DC (2007).

49. C. J. Tucker, J. E. Pinzon, and M. E. Brown, "Global inventory modeling and mapping studies," NA94apr15b.n11-VIg, 2.0., Global Land Cover Facility, University of Maryland, College Park, MD (2004).

50. R. Nemani et al., "Monitoring and forecasting ecosystem dynamics using the Terrestrial Observation and Prediction System (TOPS)," Rem. Sens. Environ. 113(7), 1497-1509 (2009), http://dx.doi.org/10.1016/j.rse.2008.06.017.

51. B. N. Holben, "Characteristics of maximum-value composite images from temporal AVHRR data," Int. J. Rem. Sens. 7(11), 1417-1434 (1986), http://dx.doi.org/10.1080/ 01431168608948945.

52. J. Pinzon, M. E. Brown, and C. J. Tucker, "Satellite time series correction of orbital drift artifacts using empirical mode decomposition," in Hilbert-Huang Transform and its Applications, World Scientific, pp. 167-186 (2005).

53. W. M. Jolly et al., "A flexible, integrated system for generating meteorological surfaces derived from point sources across multiple geographic scales," Environ. Modell. Softw. 20(7), 873-882 (2005), http://dx.doi.org/10.1016/j.envsoft.2004.05.003.

54. C. J. Tucker et al., "An extended AVHRR 8-km NDVI dataset compatible with MODIS and SPOT vegetation NDVI data," Int. J. Rem. Sens. 26(20), 4485-4498 (2005), http://dx.doi .org/10.1080/01431160500168686.

55. J. A. Sobrino et al., "NOAA-AVHRR orbital drift correction from solar zenithal angle data," IEEE Trans. Geosci. Rem. Sens. 46(12), 4014-4019 (2008), http://dx.doi.org/10.1109/ TGRS.2008.2000798.

56. P. S. A. Beck et al., "Improved monitoring of vegetation dynamics at very high latitudes: a new method using MODIS NDVI," Rem. Sens. Environ. 100(3), 321-334 (2006), http://dx .doi.org/10.1016/j.rse.2005.10.021.

57. M. E. Brown and K. M. de Beurs, "Evaluation of multi-sensor semi-arid crop season parameters based on NDVI and rainfall," Rem. Sens. Environ. 112(5), 2261-2271 (2008), http://dx .doi.org/10.1016/j.rse.2007.10.008.

58. R. Stöckli and P. L. Vidale, "European plant phenology and climate as seen in a 20-year AVHRR land-surface parameter dataset," Int. J. Rem. Sens. 25(17), 3303-3330 (2004), http://dx.doi.org/10.1080/01431160310001618149.

59. Y. Julien and J. A. Sobrino, "Global land surface phenology trends from GIMMS database," International J. Rem. Sens. 30(13), 3495-3513 (2009), http://dx.doi.org/10.1080/ 01431160802562255 .

60. M. A. White et al., "Intercomparison, interpretation, and assessment of spring phenology in North America estimated from remote sensing for 1982-2006," Global Change Biol. 15(10), 2335-2359 (2009), http://dx.doi.org/10.1111/gcb.2009.15.issue-10.

61. J. F. Hermance et al., "Extracting phenological signals from multiyear AVHRR NDVI time series: framework for applying high-order annual splines with roughness damping," IEEE Trans. Geosci. Rem. Sens. 45(10), 3264-3276 (2007), http://dx.doi.org/10.1109/TGRS .2007.903044.

62. W. Zhu et al., "A changing-weight filter method for reconstructing a high-quality NDVI time series to preserve the integrity of vegetation phenology," IEEE Trans. Geosci. Rem. Sens. 50(4), 1085-1094 (2012), http://dx.doi.org/10.1109/TGRS.2011 .2166965 .

63. E. Ito et al., "Leaf-shedding phenology in Lowland Tropical Seasonal Forests of Cambodia as estimated from NOAA satellite images," IEEE Trans. Geosci. Rem. Sens. 46(10), $2867-$ 2871 (2008), http://dx.doi.org/10.1109/TGRS.2008.919820.

64. K. M. de Beurs and G. M. Henebry, "Spatio-temporal statistical methods for modelling land surface phenology," in Phenological Research, I. L.Hudson and M. R. Keatley, eds., Springer Netherlands, Dordrecht, pp. 177-208 (2010). 
65. P. Jonsson and L. Eklundh, "Seasonality extraction by function fitting to time-series of satellite sensor data," IEEE Trans. Geosci. Rem. Sens. 40(8), 1824-1832 (2002), http://dx.doi .org/10.1109/TGRS.2002.802519.

66. P. Jönsson and L. Eklundh, "TIMESAT - a program for analyzing time-series of satellite sensor data," Computers \& Geosciences 30(8), 833-845 (2004), http://dx.doi.org/10.1016/j .cageo.2004.05.006.

67. A. Bachoo and S. Archibald, "Influence of using date-specific values when extracting phenological metrics from 8-day composite NDVI data," in Proc. International Workshop on the Analysis of Multi-temporal Remote Sensing Images, pp. 1-4, IEEE (2007).

68. J. N. Hird and G. J. McDermid, "Noise reduction of NDVI time series: an empirical comparison of selected techniques," Rem. Sens. Environ. 113(1), 248-258 (2009), http://dx.doi .org/10.1016/j.rse.2008.09.003.

69. D. Peppin et al., "Post-wildfire seeding in forests of the western United States: an evidencebased review," Forest Ecol. Manage. 260(5), 573-586 (2010), http://dx.doi.org/10.1016/j .foreco.2010.06.004.

70. K. Steenkamp et al., "Long-term phenology and variability of Southern African vegetation," in Proc. IEEE International Geoscience and Remote Sensing Symposium, Vol. 3, pp. III816-III-819, IEEE (2008).

71. L. Eklundh and P. Jonsson, TIMESAT 3.0 Software Manual (2010).

72. F. Gao et al., "An Algorithm to produce temporally and spatially continuous MODIS-LAI time series," IEEE Geosci. Rem. Sens. Lett. 5(1), 60-64 (2008), http://dx.doi.org/10.1109/ LGRS.2007.907971.

73. X. Zhang et al., "Climate controls on vegetation phenological patterns in northern mid- and high latitudes inferred from MODIS data," Global Change Biol. 10(7) 1133-1145 (2004), http://dx.doi.org/10.1111/gcb.2004.10.issue-7.

74. D. A. Orwig et al., "Multi-year ecosystem response to hemlock woolly adelgid infestation in southern New England forests," Can. J. Forest Res. 38(4), 834-843 (2008), http://dx.doi .org/10.1139/X07-196.

75. A. K. Eschtruth et al., "Vegetation dynamics in declining eastern hemlock stands: 9 years of forest response to hemlock woolly adelgid infestation," Can. J. Forest Res. 36(6), 14351450 (2006), http://dx.doi.org/10.1139/x06-050.

76. G. M. Lovett et al., "Forest ecosystem responses to exotic pests and pathogens in Eastern North America," BioScience 56(5), 395-405 (2006), http://dx.doi.org/10.1641/0006-3568 (2006)056[0395:FERTEP]2.0.CO;2.

77. D. Potere et al., "Patterns in forest clearing along the appalachian trail corridor," Photogram. Eng. Rem. Sens. 73(7), 783 (2007).

78. M. A. Drummond and T. R. Loveland, "Land-use pressure and a transition to forest-cover loss in the Eastern United States," BioScience 60(4), 286-298 (2010), http://dx.doi.org/10 $.1525 /$ bio.2010.60.4.7.

79. M. C. Hansen, S. V. Stehman, and P. V. Potapov, "Quantification of global gross forest cover loss," PNAS 107(19), 8650-8655 (2010), http://dx.doi.org/10.1073/pnas.0912668107.

80. S.-J. Jeong et al., "Phenology shifts at start vs. end of growing season in temperate vegetation over the Northern Hemisphere for the period 1982-2008," Global Change Biol. 17(7), 2385-2399 (2011), http://dx.doi.org/10.1111/j.1365-2486.2011.02397.x.

81. L. Zhou et al., "Variations in northern vegetation activity inferred from satellite data of vegetation index during 1981 to 1999," J. Geophys. Res. 106(D17) 20069-20083 (2001), http://dx.doi.org/10.1029/2000JD000115.

82. J. Zhao, Y. Wang, and H. Zhang, "Automated batch processing of mass remote sensing and geospatial data to meet the needs of end users," in Proc. IEEE International Geoscience and Remote Sensing Symposium, pp. 3464-3467, IEEE (2011).

83. G. R. van der Werf et al., "Continental-scale partitioning of fire emissions during the 1997 to 2001 El Nino/La Nina period,” Science 303(5654), 73 (2004), http://dx.doi.org/10.1126/ science. 1090753.

84. J. Fang et al., "Changes in forest biomass carbon storage in china between 1949 and 1998," Science 292(5525), 2320-2322 (2001), http://dx.doi.org/10.1126/science. 1058629. 


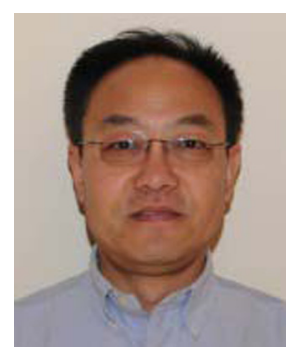

Yeqiao Wang received his $\mathrm{MS}$ and $\mathrm{PhD}$ in natural resources management and engineering from the University of Connecticut in 1992 and 1995, respectively. He is currently a professor of terrestrial remote sensing at the Department of Natural Resources Science, University of Rhode Island, USA.

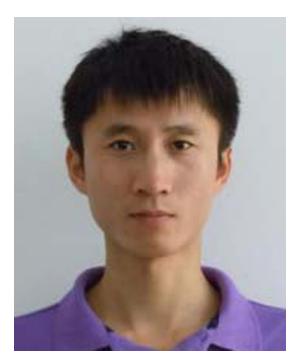

Jianjun Zhao received his BS in 2007 from the School of Urban and Environmental Sciences, Northeast Normal University, Changchun, China, where he is currently working toward a $\mathrm{PhD}$ in remote sensing. $\mathrm{He}$ is also currently a visiting $\mathrm{PhD}$ student at the Department of Natural Resource Science, University of Rhode Island, USA. His research interests are remote sensing of terrestrial ecosystems, data processing, and applications.

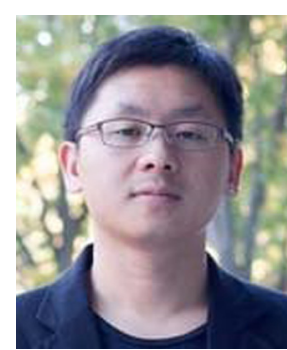

Yuyu Zhou received his $\mathrm{PhD}$ in environmental sciences from the University of Rhode Island, where he studied land use and land cover change and its impact on the environment. He then worked as a postdoctoral research associate at Purdue University and performed high-resolution fossil-fuel $\mathrm{CO}_{2}$ emissions modeling studies at national and city scales. Currently, he is a scientist conducting global climate change research at the Pacific Northwest National Laboratory as part of a diverse, interdisciplinary group of scientists who develop and apply an integrated global land use-energy-economy model.

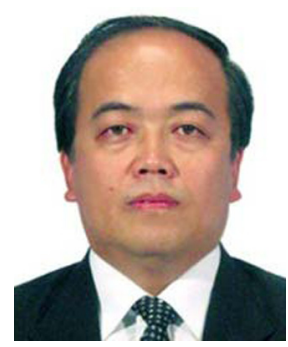

Hongyan Zhang received his $\mathrm{PhD}$ from the Institute of Geographic Sciences and Natural Resources Research, Chinese Academy of Sciences. He is currently a professor in GIS and remote sensing with the School of Urban and Environmental Sciences, Northeast Normal University, Changchun, China. His main research interests are applications of GIS and remote sensing and geoinformatic presentation. 